\title{
Soils suppressive against Gaeumannomyces graminis var. tritici identified under wheat crop monoculture in southern Chile
}

\author{
Orlando Andrade 1 , Ricardo Campillo ${ }^{2}$, Amelia Peyrelongue ${ }^{3}$, and Leticia \\ Barrientos ${ }^{4}$ \\ 'Escuela de Agronomía, Universidad Católica de Temuco, Casilla 15-D, Temuco, Chile. \\ ${ }^{2}$ Instituto de Investigaciones Agropecuarias, Centro Regional de Investigación INIA-Carillanca, Casilla \\ 58-D, Temuco, Chile. \\ ${ }^{3}$ Formerly Researcher at Centro Regional de Investigación INIA-Carillanca, Casilla 58-D, Temuco, Chile. \\ ${ }^{4}$ Laboratorio de Biología Molecular y Farmacogenética, Facultad de Medicina, Universidad de la Frontera, \\ Casilla 54-D, Temuco, Chile.
}

\begin{abstract}
O. Andrade, R. Campillo, A. Peyrelongue, and L. Barrientos. 2011. Soils suppressive against Gaeumannomyces graminis var. tritici identified under wheat crop monoculture in southern Chile. Cien. Inv. Agr. 38(3):345-356. Improved knowledge of the biological phenomenon of soil suppressiveness is critical for the management and biological control of soilborne pathogens. Andisols, which are located in southern Chile, show very high conduciveness to the take-all disease of wheat caused by the fungal soil-borne pathogen Gaeumannomyces graminis var. tritici. However, no previous reports have investigated suppressive soils in this important wheat-producing area. The first part of this study was conducted to identify soils suppressive to the take-all disease, and will be followed by a characterization of its microflora to identify potential bio-control agents against the fungal pathogen. Based on the transferability of suppressiveness into the same sterile soil background, 20 soils were collected from different wheat-growing areas in southern Chile and were classified as either suppressive or conducive to the take-all disease under artificial inoculation in a greenhouse environment. Five soils were found to have highly suppressive properties to the take-all disease of wheat, and suppressiveness was observed in soils with a long history of wheat monoculture. Suppressive and conducive soils were found to have overlapping physicochemical characteristics. This is the first report of soils suppressive to take-all of wheat in Chile.
\end{abstract}

Key words: Biological control, Gaeumannomyces graminis var. tritici, take-all suppressive soils.

\section{Introduction}

Take-all disease of wheat, caused by Gaeumannomyces graminis (Sacc.) Arx \& Olivier var. tritici Walker (Ggt), is the most damaging root

Received June 16, 2010. Accepted August 22, 2011.

Corresponding author: oandrade@uct.cl disease affecting wheat worldwide and has caused significant decreases in yield in many wheatgrowing areas (Duffy et al., 1997; Hornby, 1998).

Numerous experimental evidence convincingly corroborated the observations of Glynne in England (around 1935) regarding the reduction in the severity of take-all under monoculture of wheat 
(Borneman and Becker, 2007) and the biological nature of this phenomenon (Weller et al., 2002). Much attention has therefore been given to this kind of soils in the hopes of identifying an innovative approach for controlling the disease. The hypothesis that an antagonist microflora builds up under wheat monoculture has been supported by numerous studies on soils suppressive to takeall, which demonstrate the association between a decline in the severity of the disease and the continuous cropping of wheat (Weller et al., 2002; Garbeva et al., 2004). Despite the limited understanding of the phenomenon and increasing complexity owing to the many different types of take-all suppressiveness reported, various groups of researchers in many countries have been investigating suppressive soils as a source of Ggt biocontrol agents (Hornby, 1998).

The transferability of suppressiveness to steamtreated or sterile soils has been extensively used in studies to demonstrate the properties of soils suppressive to take-all and to identify the biological character involved (Andrade et al., 1994; Weller et al., 2002; Borneman and Becker, 2007).

Take-all is the most severe disease affecting wheat crops in southern Chile, and there are no previous reports of soils in Chile suppressive to take-all. Because suppressive soils may yield microorganisms with potential use as biocontrol agents of Ggt, research has been conducted to determine whether suppressive soils have arisen under wheat monoculture crop systems within particular areas of southern Chile. It is nevertheless evident that further biological analysis is required.

\section{Materials and methods}

\section{Soil sampling}

Soils were collected from different wheat-growing areas located at the Bío-Bío and La Araucanía regions of southern Chile (Table 1), primarily from low-input wheat-cropping farmers with a long history of monoculture. Previous results obtained with soils coming from Andisols, namely from high-input cropping farmers with four to six years of wheat monoculture, showed the absence of suppressive factors in those soils. In all cases, bulk soil was randomly collected from the top 20 $\mathrm{cm}$, sieved on a $0.25 \mathrm{~cm}^{2}$ mesh openings, placed in dark-colored plastic containers, and stored at 5 ${ }^{\circ} \mathrm{C}$ until used.

\section{Inoculum preparation}

A single, highly pathogenic isolate of Ggt, maintained every year on artificially inoculated wheat plants in soil for take-all experimental plots, was used for all inoculations. Oat kernel inoculum was prepared as described by Mathre (1992), except that autoclaving was done twice on two consecutive days for $30 \mathrm{~min}$ each time. Dry infested kernels were blended, sieved to a particle size of $0.5-1.0 \mathrm{~mm}$, and stored in dried sterile glass flasks at $5{ }^{\circ} \mathrm{C}$ until used.

Screening of soils for transferability of Ggt suppressive factors

All soils were tested to determine their suppressive or conducive properties against the take-all disease of wheat, based on the presence and transferability of suppressive factors into the same sterile soil background. The experiments were carried out in an air-conditioned glasshouse where the temperature was maintained between 15 and $20^{\circ} \mathrm{C}$ and recorded every two hours by a Tiny Tag Data Logger (Gemini Data Loggers, UK).

Experiments were performed as previously described (Andrade et al., 1994). Briefly, plastic containers (2.2 $\mathrm{cm}$ diameter $\mathrm{x} 14 \mathrm{~cm}$ long), holding a perforated cap with a cotton layer at the bottom, were filled with an $11 \mathrm{~cm}$ column of $2 \mathrm{~mm}$-sieved soil and distributed in a wooden perforated container with 150 racks. A single disinfected seed $(15 \%$ ethanol $+1 \%$ sodium hypochlorite for $2 \mathrm{~min}$ ) of Dalcahue-INIA spring 
Table 1. Location and cropping history of 20 soils collected in southern Chile and screened for suppressiveness to the take-all disease of wheat.

\begin{tabular}{|c|c|c|c|}
\hline Soil & Location & GPS coordenates & Cropping history \\
\hline 1 & P. 24 INIA Carillanca. La Araucanía. & S $38^{\circ} 41^{\prime} 21^{\prime \prime}$ - WO $72^{\circ} 25^{\prime} 35^{\prime \prime}$ & Wheat monoculture for about 25 years \\
\hline 2 & Danquilco - Niágara. La Araucanía. & S $38^{\circ} 45^{\prime} 35^{\prime \prime}$ - WO $72^{\circ} 26^{\prime} 20^{\prime \prime}$ & $\begin{array}{l}\text { Mostly wheat broken by } 1 \text { year of pastures every } \\
3 \text { years }\end{array}$ \\
\hline 3 & Sta. Rosa. Chillán, Bío-Bío. & S $36^{\circ} 31^{\prime} 45^{\prime \prime}-$ WO $71^{\circ} 54^{\prime} 41^{\prime \prime}$ & Wheat monoculture for about 18 years \\
\hline 4 & San Ignacio 1. Bío-Bío. & S $36^{\circ} 49^{\prime} 24^{\prime \prime}$ - WO $71^{\circ} 55^{\prime} 07^{\prime \prime}$ & Wheat monoculture for about 8 years \\
\hline 5 & San Ignacio 2. Bío-Bío. & S $36^{\circ} 49^{\prime} 24^{\prime \prime}-$ WO $71^{\circ} 55^{\prime} 07^{\prime \prime}$ & $\begin{array}{l}\text { Crop rotation with wheat, rapeseed, oat, lentil, } \\
\text { and wheat }\end{array}$ \\
\hline 6 & Cardas-Toscas. Victoria, La Araucanía. & S $38^{\circ} 19^{\prime} 40^{\prime \prime}$ - WO $72^{\circ} 17^{\prime} 16^{\prime \prime}$ & $\begin{array}{l}\text { Mostly wheat broken by } 1 \text { year of pastures every } \\
2 \text { years }\end{array}$ \\
\hline 7 & $\begin{array}{l}\text { Cardas-Toscas (P. 126). Victoria, La } \\
\text { Araucanía. }\end{array}$ & S $38^{\circ} 19^{\prime} 28^{\prime \prime}-$ WO $72^{\circ} 17^{\prime} 11^{\prime \prime}$ & Wheat monoculture for about 15 years \\
\hline 8 & Guadaco. Quino, La Araucanía. & S $38^{\circ} 19^{\prime} 23^{\prime \prime}-$ WO $72^{\circ} 30^{\prime} 38^{\prime \prime}$ & $\begin{array}{l}\text { Mostly wheat broken by } 1 \text { year of barley every } \\
3 \text { years }\end{array}$ \\
\hline 9 & $\begin{array}{l}\text { Reducción Cahuín. Victoria, La } \\
\text { Araucanía. }\end{array}$ & S $38^{\circ} 17^{\prime} 14^{\prime \prime}-$ WO $72^{\circ} 17^{\prime} 57^{\prime \prime}$ & $\begin{array}{l}\text { Mostly wheat broken by } 1 \text { year of pastures every } \\
3 \text { years }\end{array}$ \\
\hline 10 & $\begin{array}{l}\text { Sector Pichiquiniñao. Victoria, La } \\
\text { Araucanía. }\end{array}$ & S $38^{\circ} 22^{\prime} 17^{\prime \prime}-$ WO $72^{\circ} 20^{\prime} 40^{\prime \prime}$ & $\begin{array}{l}\text { Mostly wheat broken by } 1 \text { year of pastures every } \\
2-3 \text { years }\end{array}$ \\
\hline 11 & Pichoy, km 4. Púa, La Araucanía. & S $38^{\circ} 20^{\prime} 51^{\prime \prime}-$ WO $72^{\circ} 25^{\prime} 28^{\prime \prime}$ & Wheat monoculture for the last 12 years \\
\hline 12 & El Peñasco, Km 14 Púa, La Araucanía. & $\mathrm{S} 38^{\circ} 21^{\prime} 5^{\prime \prime}-\mathrm{WO} 72^{\circ} 30^{\prime} 10^{\prime \prime}$ & Wheat monoculture for the last 10 years \\
\hline 13 & $\begin{array}{l}\text { Las Vertientes - Challacura. Púa, La } \\
\text { Araucanía. }\end{array}$ & S $38^{\circ} 22^{\prime} 50^{\prime \prime}-$ WO $72^{\circ} 23^{\prime} 56^{\prime \prime}$ & Wheat monoculture for the last 10 years \\
\hline 14 & $\begin{array}{l}\text { Las Vertientes - Zafira. Púa, La } \\
\text { Araucanía. }\end{array}$ & S $38^{\circ} 23^{\prime} 5^{\prime \prime}$ - WO $72^{\circ} 24^{\prime} 37^{\prime \prime}$ & Wheat monoculture for the last 10 years \\
\hline 15 & Quilaco- Niágara, 1. La Araucanía. & S $38^{\circ} 44^{\prime} 03^{\prime \prime}$ - WO $72^{\circ} 27^{\prime} 05^{\prime \prime}$ & $\begin{array}{l}\text { Mostly wheat broken by } 1 \text { year of pastures every } \\
3 \text { years }\end{array}$ \\
\hline 16 & Quilaco-Niágara, 2. La Araucanía. & S $38^{\circ} 43^{\prime} 39^{\prime \prime}-$ WO $72^{\circ} 27^{\prime} 31^{\prime \prime}$ & $\begin{array}{l}\text { Mostly wheat broken by } 1 \text { year of pastures every } \\
3 \text { years }\end{array}$ \\
\hline 17 & Yuco-Tres Cerros. La Araucanía. & S $38^{\circ} 44^{\prime} 02^{\prime \prime}-$ WO $72^{\circ} 29^{\prime} 22^{\prime \prime}$ & Wheat and 2 years of pastures in between \\
\hline 18 & $\begin{array}{l}\text { Ihuilmahuida-Tres Cerros. La } \\
\text { Araucanía. }\end{array}$ & S $38^{\circ} 43^{\prime} 51^{\prime \prime}-$ WO $72^{\circ} 28^{\prime} 25^{\prime \prime}$ & Wheat monoculture for the last 8 years \\
\hline 19 & Curaco - Tres Cerros. La Araucanía. & S $38^{\circ} 44^{\prime} 38^{\prime \prime}-$ WO $72^{\circ} 28^{\prime} 41^{\prime \prime}$ & $\begin{array}{l}\text { Mostly wheat broken by } 1 \text { year of pastures every } \\
2-3 \text { years }\end{array}$ \\
\hline 20 & El Panal, Quino. La Araucanía. & S $38^{\circ} 19^{\prime} 50^{\prime \prime}-$ WO $72^{\circ} 35^{\prime} 33^{\prime \prime}$ & Wheat monoculture for the last 6 years \\
\hline
\end{tabular}

wheat, sieved for size homogeneity, was planted in each container. Containers were watered the first time with a nutrient solution made in distilled water. Thereafter, the containers were watered with distilled water only every 3 days, and a consistent volume was dispensed in each container using a precision dispenser (Master Flex, Barrington, IL, USA).
The treatments were as follows: sterile soil with or without $0.1 \%$ Ggt inoculum, untreated soil with or without $0.1 \%$ inoculum, and sterile soil $+1 \%$ untreated (natural, air-dried) soil with or without $0.1 \%$ inoculum. All the treatments for each soil tested were applied to 15 containers arranged in a completely randomized design. 
After 40 days, the seedlings were carefully removed from the soil by submerging a sieve with the soil core into a container filled with tap water. The roots were individually assessed for infection, and the percentage of root blackening against a white background, on a $0-100 \%$ scale, was recorded. Shoots were excised at the crown, placed into individual paper envelopes, and dried at $70{ }^{\circ} \mathrm{C}$ for $72 \mathrm{H}$ to obtain the shoot dry weight.

The level of disease and effectiveness of the inoculum and the inoculation procedures were determined by comparing the treatments on sterile soil with or without inoculum. The presence of suppressive factors within each soil was determined by comparing the root blackening and shoot dry weight of both treatments on sterile infested soil (with or without $1 \%$ of untreated soil) and on untreated soil.

An additional test to check the reproducibility of the suppressiveness/conduciveness response was performed with two soils that showed high and low expression of suppresiveness in the screening test.

The root blackening percentages and shoot dry weights for each soil were statistically analyzed for variance and least significant difference by using the MSUSTA Statistical Analysis Package Version 5.0 for microcomputers, developed by Richard E. Lund, Research and Development Institute Inc., Montana State University, Montana, USA.

Physical-chemical analysis of suppressive and conducive soils

Five soils classified as suppressive and two as conducive to take-all disease of wheat were physically and chemically analyzed. All analyses were carried out at the Laboratorio de Análisis de Suelos of INIA Carillanca, which has been offering this service to farmers for more than 30 years. The chemical analysis was performed according to the methodology described in Sparks (1996), which considers soil acidity parameters and the content of the major macro- and micronutrients and organic matter. The macronutrient analysis included initial $\mathrm{N}$; extractable $\mathrm{P}, \mathrm{K}, \mathrm{S}, \mathrm{Ca}$, and $\mathrm{Mg}$; and $\mathrm{Na}$ exchange. The $\mathrm{pH}$ was also determined, using water, $\mathrm{CaCl}_{2}$, and interchangeable $\mathrm{Al}$, to calculate the effective exchange cationic capacity (EECC) and the percentage of Al saturation.

\section{Results}

\section{Soil sampling}

A total of 20 soils collected from low-input farms at different locations between the Bío-Bío and La Araucanía regions of southern Chile were analyzed (Table 1). Ten of them, 1, 3, 4, 7, 11, 12, 13, 14, 18, and 20 , had a long history of wheat monoculture, while nine soils, 2, 6, 8, 9, 10, 15, 16, 17 and 19, had also been used for pasture or barley cultivation. One soil, 5, was under a crop rotation system.

All soils, excluding 1, 3, 4,5 and 20, which came from experimental sites with good levels of soil fertility, came from low-input cropping systems primarily owned by small farmers practicing subsistence agriculture. All the collected soils were under wheat cultivation at the time of collection, except for soils 2 and 19, which were under pasture.

Screening for transferability of Ggt suppressive factors in the soils

Disease developed in all the experiments at the inoculum rate used (Tables 2 and 3). The infection in the inoculated sterile soil treatments was fairly homogeneous, and ranged from 80 to $97 \%$, except in soils 5 and 20, which had infections of 55 and $69 \%$, respectively. There was a significant and negative correlation $\left(\mathrm{r}^{2}=-0.78\right)$ between the level of infection and shoot dry weight. The latter parameter was reduced by $55 \%$ because of the disease, when comparing the Ggt non-inoculated and inoculated sterile soil treatments (Treatments 1 and 2, respectively). None of the sterile noninoculated treatments showed root infection. 
Table 2. Root infection and shoot dry weight of wheat plants for the identification of soils suppressive or conducive to the take-all disease of wheat.

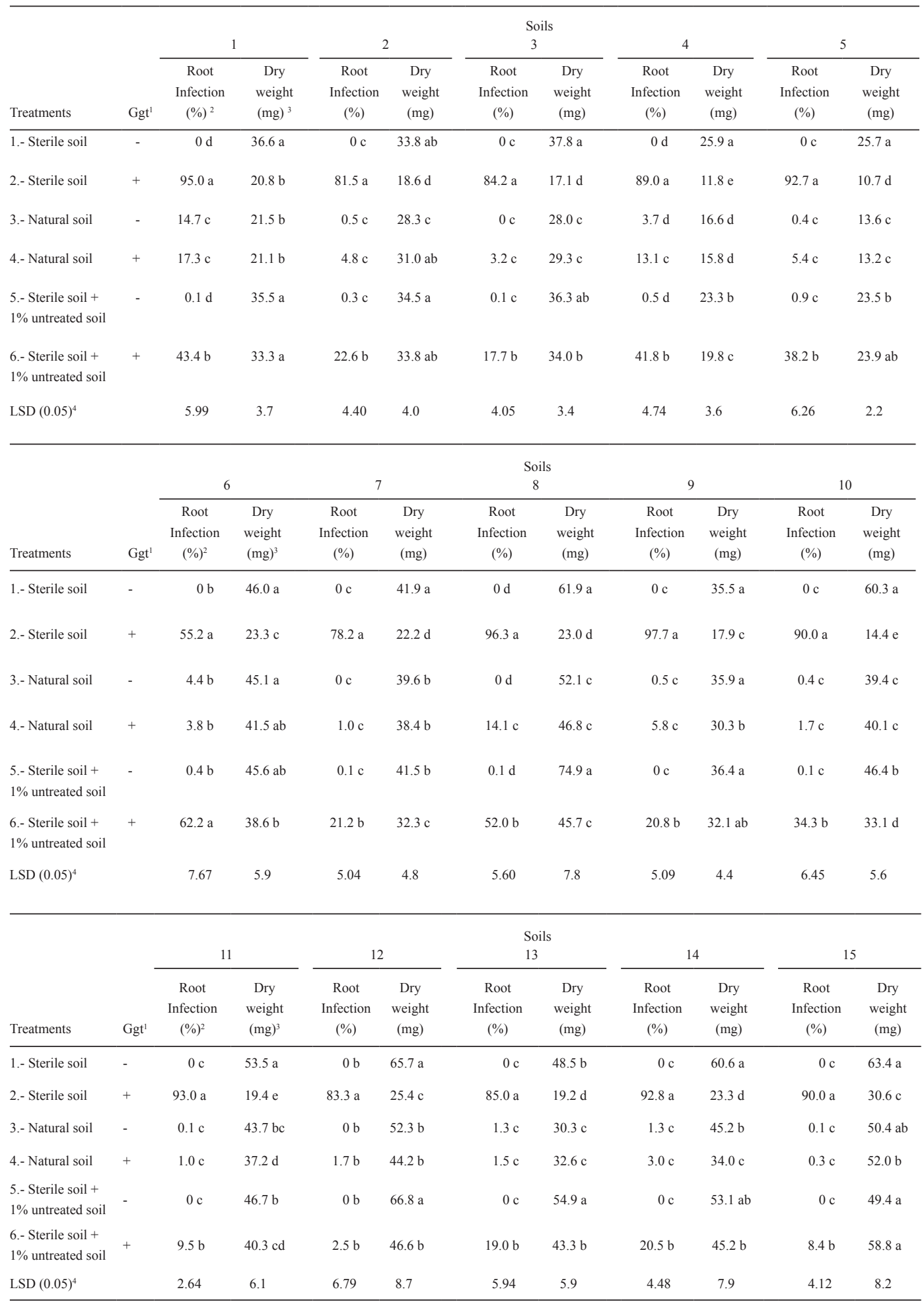




\begin{tabular}{|c|c|c|c|c|c|c|c|c|c|c|c|}
\hline \multirow[b]{2}{*}{ Treatments } & \multirow[b]{2}{*}{$\mathrm{Ggt}^{1}$} & \multicolumn{2}{|c|}{16} & \multicolumn{2}{|c|}{17} & \multicolumn{2}{|c|}{$\begin{array}{c}\text { Soils } \\
18\end{array}$} & \multicolumn{2}{|c|}{19} & \multicolumn{2}{|c|}{20} \\
\hline & & $\begin{array}{c}\text { Root } \\
\text { Infection } \\
(\%)^{2}\end{array}$ & $\begin{array}{c}\text { Dry } \\
\text { weight } \\
(\mathrm{mg})^{3}\end{array}$ & $\begin{array}{c}\text { Root } \\
\text { Infection } \\
(\%)\end{array}$ & $\begin{array}{c}\text { Dry } \\
\text { weight } \\
(\mathrm{mg})\end{array}$ & $\begin{array}{c}\text { Root } \\
\text { Infection } \\
(\%)\end{array}$ & $\begin{array}{c}\text { Dry } \\
\text { weight } \\
(\mathrm{mg})\end{array}$ & $\begin{array}{c}\text { Root } \\
\text { Infection } \\
(\%)\end{array}$ & $\begin{array}{c}\text { Dry } \\
\text { weight } \\
(\mathrm{mg})\end{array}$ & $\begin{array}{c}\text { Root } \\
\text { Infection } \\
(\%)\end{array}$ & $\begin{array}{c}\text { Dry } \\
\text { weight } \\
(\mathrm{mg})\end{array}$ \\
\hline 1.- Sterile soil & - & $0 \mathrm{c}$ & $71.6 \mathrm{a}$ & $0 \mathrm{~d}$ & $63.5 \mathrm{a}$ & $0 \mathrm{c}$ & $61.2 \mathrm{a}$ & $0 \mathrm{~d}$ & $57.5 \mathrm{ab}$ & $0 \mathrm{c}$ & $88.3 \mathrm{a}$ \\
\hline 2.- Sterile soil & + & $91.5 \mathrm{a}$ & $29.0 \mathrm{c}$ & $96.2 \mathrm{a}$ & $19.9 \mathrm{~d}$ & $81.7 \mathrm{a}$ & $28.9 \mathrm{c}$ & $99.6 \mathrm{a}$ & $20.1 \mathrm{~d}$ & $69.0 \mathrm{~b}$ & $42.1 \mathrm{c}$ \\
\hline 3.- Natural soil & - & $0.1 \mathrm{c}$ & $49.7 \mathrm{~b}$ & $0.1 \mathrm{~d}$ & $47.0 \mathrm{~b}$ & $0.1 \mathrm{c}$ & $48.6 \mathrm{~b}$ & $0.1 \mathrm{~d}$ & $52.2 \mathrm{~b}$ & $0 \mathrm{c}$ & $53.9 \mathrm{~b}$ \\
\hline 4.- Natural soil & + & $0.1 \mathrm{c}$ & $50.2 \mathrm{~b}$ & $9.0 \mathrm{c}$ & $32.0 \mathrm{c}$ & $4.5 \mathrm{c}$ & $42.4 \mathrm{~b}$ & $17.0 \mathrm{c}$ & $41.2 \mathrm{c}$ & $2.3 \mathrm{c}$ & $41.1 \mathrm{c}$ \\
\hline $\begin{array}{l}\text { 5.- Sterile soil + } 1 \% \\
\text { untreated soil }\end{array}$ & - & $0.1 \mathrm{c}$ & $63.8 \mathrm{a}$ & $0 \mathrm{~d}$ & $53.4 \mathrm{~b}$ & $0 \mathrm{c}$ & $65.0 \mathrm{a}$ & $0 \mathrm{~d}$ & $64.5 \mathrm{a}$ & $0.1 \mathrm{c}$ & $90.4 \mathrm{a}$ \\
\hline $\begin{array}{l}\text { 6.- Sterile soil + } 1 \% \\
\text { untreated soil }\end{array}$ & + & $6.7 \mathrm{~b}$ & $55.7 \mathrm{~b}$ & $78.5 \mathrm{~b}$ & $22.2 \mathrm{~d}$ & $45.9 \mathrm{~b}$ & $27.8 \mathrm{c}$ & $87.9 \mathrm{~b}$ & $25.3 \mathrm{~d}$ & $83.7 \mathrm{a}$ & $31.2 \mathrm{~d}$ \\
\hline $\operatorname{LSD}(0.05)^{4}$ & & 2.34 & 8.1 & 4.30 & 6.6 & 6.39 & 7.8 & 3.92 & 7.4 & 7.06 & 7.8 \\
\hline
\end{tabular}

${ }^{1}$ Rate of inoculum: $0.1 \% \mathrm{w} / \mathrm{w}$

${ }^{2}$ Root infection measured after 40-day growth (0-100\%).

${ }^{3}$ Shoot dry weight measured after 40-day growth.

${ }^{4}$ Least significant differences based on Tukey test $(\mathrm{P}<0.05)$. Values in a column followed by the same letter are not significantly different.

$\mathrm{N}^{\mathrm{o}}$ of replications per treatment $=24$ to 28 .

About half of the soils collected from low-input farming systems exhibited a transferable suppressive factor, i.e. specific suppressiveness, sensitive to heat sterilization (Table 3) when 1\% of untreated soil was added to the same but sterile soil background. However, there was significant variability in the magnitudes of the responses. The strongest responses, having both the lowest root infections and shoot dry weights closest to the respective non-inoculated treatments (Treatments 5 and 6), were observed in soils 2, 3, 7, 9, $11,12,13,14,15$, and 16 . In all these soils, the level of infection in sterile soil $+1 \%$ of untreated soil (Treatment 6) was dramatically lower compared to the same treatment with no untreated soil (Treatment 2). The root infection level decreased in these 10 soils from an average of $87.7 \%$ in the treatment with sterile soil alone $+\mathrm{Ggt}$, to an average of $14.9 \%$ when $1 \%$ of untreated soil was added. This significant response in reducing the root infection level consequently increased the shoot dry weight up to $83.8 \%$ of the weight from the sterile soil non-inoculated treatment. Soils $1,4,5,8$, and 10 showed a low level of suppressiveness, and soils $6,17,18,19$, and 20 showed a high level of conduciveness. For the soils in the latter group, the addition of $1 \%$ of the natural soil to the same but sterile soil background did not significantly alter the extent of root infection or the shoot dry weight.

Independent of the degree of specific suppression showed by most of the soils, all of the soils showed different levels of general suppression. In most cases, data obtained for the inoculated natural soil (Treatment 4) revealed a high degree of general suppression that reduced the root infection and increased the shoot dry weight, relative to the inoculated sterile soil treatment (Treatment 2). Most of the soils that showed high levels of transferable specific suppression had the lowest root disease levels and the highest shoot dry weights in the inoculated natural soil. In the soils found to be conducive to the take-all disease of wheat, this response was much lower.

The experiments carried out to reproduce the responses in two soils, one suppressive and the other conducive to the take-all disease of wheat, effectively supported the previous findings (Table 3). In the current study, soil 7 was confirmed as a suppressive soil, and soil 17 was confirmed as a conducive soil. 
Table 3. Root infection and shoot dry weight of wheat plants to corroborate the two soils suppressive or conducive properties previously showed to take-all disease of wheat.

\begin{tabular}{|c|c|c|c|c|c|}
\hline \multirow[b]{3}{*}{ Treatments } & \multirow[b]{3}{*}{ Ggt $^{1}$} & \multicolumn{4}{|c|}{ Soils } \\
\hline & & \multicolumn{2}{|c|}{7 (Suppressive) } & \multicolumn{2}{|c|}{17 (Conducive) } \\
\hline & & $\begin{array}{l}\text { Root Infection } \\
(\%)^{2}\end{array}$ & $\begin{array}{l}\text { Dry weight } \\
(\mathrm{mg})^{3}\end{array}$ & $\begin{array}{c}\text { Root Infection } \\
(\%)\end{array}$ & $\begin{array}{l}\text { Dry weight } \\
(\mathrm{mg})\end{array}$ \\
\hline 1.- Sterile soil & - & $0.0 \mathrm{ab}$ & $40.2 \mathrm{db}$ & $0.0 \mathrm{ab}$ & $36.8 \mathrm{cb}$ \\
\hline 2.- Sterile soil & + & $78.8 \mathrm{~b}$ & $21.0 \mathrm{a}$ & $63.8 \mathrm{~b}$ & $18.5 \mathrm{a}$ \\
\hline 3.- Natural soil & - & $0.5 \mathrm{a}$ & $35.4 \mathrm{bc}$ & $0.9 \mathrm{a}$ & $34.3 \mathrm{bc}$ \\
\hline 4.- Natural soil & + & $1.4 \mathrm{a}$ & $35.2 \mathrm{~b}$ & $60.0 \mathrm{~b}$ & $19.3 \mathrm{a}$ \\
\hline 5.- Sterile soil $+1 \%$ untreated soil & - & $0.0 \mathrm{a}$ & $39.4 \mathrm{~cd}$ & $0.0 \mathrm{a}$ & $33.1 \mathrm{~b}$ \\
\hline 6.- Sterile soil $+1 \%$ untreated soil & + & $1.3 \mathrm{a}$ & $38.1 \mathrm{bcd}$ & $65.0 \mathrm{~b}$ & $16.8 \mathrm{a}$ \\
\hline $\operatorname{LSD}(0.05)^{4}$ & & 4.42 & 2.68 & 4.84 & 2.14 \\
\hline
\end{tabular}

${ }^{1}$ Rate of inoculum : $0.1 \% \mathrm{w} / \mathrm{w}$

${ }^{2}$ Root infection measured after 40-day growth $(0-100 \%)$.

${ }^{3}$ Shoot dry weight measured after 40 -day growth.

${ }^{4}$ Least significant differences based on Tukey test $(\mathrm{P}<0.05)$. Values in a column followed by the same letter are not significantly different.

$\mathrm{N}^{\circ}$ of replications per treatment $=24$ to 28 .

Physicochemical analysis of suppressive and conducive soils

The physicochemical analysis performed for a group of suppressive and conducive soils to identify factors responsible for these responses did not produce any conclusive results. As seen in Table 4, none of the parameters analyzed showed clear trends that might be informative about their involvement in either the suppressive or conducive response.

The chemical characteristics substantially differed among the soils identified as suppressive. The available $\mathrm{N}$ ranged from medium to high in the five soils, the available $\mathrm{P}$ ranged from very low (4 ppm) to medium (15 ppm), and the available $\mathrm{K}$ ranged from medium $(0.39$ $\left.\mathrm{cmol}_{+} \mathrm{kg}^{-1}\right)$ to high $\left(0.82 \mathrm{cmol}_{+} \mathrm{kg}^{-1}\right)$ levels. The extractable $\mathrm{S}$ varied from high to very high in three soils and was low in two soils ( 7 and 10). Among the suppressive soils, there were some with medium $\mathrm{Ca}$ exchange content (8.25 $\left.\mathrm{cmol}_{+} \mathrm{kg}^{-1}\right)$ and others in which this parameter was low $\left(1.78 \mathrm{cmol}_{+} \mathrm{kg}^{-1}\right)$. The interchangeable $\mathrm{Mg}$ ranged from low $\left(0.30 \mathrm{cmol}_{+} \mathrm{kg}^{-1}\right)$ to high values $\left(2.08 \mathrm{cmol}_{+} \mathrm{kg}^{-1}\right)$, and the $\mathrm{Na}$ exchange varied from very low $\left(0.10 \mathrm{cmol}_{+} \mathrm{kg}^{-1}\right)$ to medium values $\left(0.24 \mathrm{cmol}_{+} \mathrm{kg}^{-1}\right)$.

The same trends were observed for the interchangeable $\mathrm{Al}$ that ranged between very low $\left(0.05 \mathrm{cmol}_{+} \mathrm{kg}^{-1}\right)$ in the Andisol 2 to high values $\left(0.70 \mathrm{cmol}_{+} \mathrm{kg}^{-1}\right)$ in the Ultisol 7. Additionally, the Al saturation ranged from very low $(0.89 \%)$ to medium values $(9.87 \%)$. The Bo appeared low in all soils, while levels of the other micronutrients were variable in two soils, the Andisol 9 and the Transitional soil $\mathrm{N}^{\circ} 10$. The $\mathrm{Zn}$ content varied from high (3.32 ppm) values in the Andisol 16 to very low values $(0.08 \mathrm{ppm})$ in the Transitional soil 9. Interestingly, some of these chemical characteristics were also observed in soils identified as conducive to the take-all disease of wheat.

As observed with the suppressive soils, the chemical analysis of the conducive soils also revealed variable chemical characteristics in the available nutrient content, bases content, and $\mathrm{Al}$ saturation percentage.

Taken together, none of the analyzed chemical parameters can explain the suppressive or conducive properties of the tested soils to the take-all disease of wheat. 
Table 4. Chemical analysis of five soils suppressive and two conducive to the take-all disease of wheat.

\begin{tabular}{|c|c|c|c|c|c|c|c|c|}
\hline \multirow[b]{2}{*}{ Indicators } & \multirow[b]{2}{*}{ Units } & \multicolumn{5}{|c|}{ Suppressive soils } & \multicolumn{2}{|c|}{ Conducive soils } \\
\hline & & 2 & 7 & 9 & 10 & 16 & 6 & 17 \\
\hline $\mathrm{N}$ & $\mathrm{mg} \mathrm{kg}^{-1}$ & 34 & 39 & 35 & 39 & 33 & 20 & 47 \\
\hline P Olsen & $\mathrm{mg} \mathrm{kg}^{-1}$ & 10 & 7 & 4 & 15 & 15 & 4 & 10 \\
\hline $\mathrm{S}$ & $\mathrm{mg} \mathrm{kg}^{-1}$ & 44 & 12 & 28 & 12 & 31 & 3 & 16 \\
\hline Organic matter & $\%$ & 17 & 9 & 18 & 12 & 14 & 9 & 14 \\
\hline pH (water) & $1: 2.5$ & 5.9 & 5.2 & 5.5 & 5.3 & 5.5 & 5.8 & 5.1 \\
\hline $\mathrm{pH}\left(\mathrm{ClCl}_{2}\right)$ & $1: 2.5$ & 5.3 & 4.8 & 5.0 & 5.0 & 4.8 & 5.0 & 4.9 \\
\hline Ca interchangeable & $\mathrm{cmol}_{+} \cdot \mathrm{kg}^{-1}$ & 4.29 & 8.25 & 1.78 & 6.16 & 2.42 & 8.76 & 3.18 \\
\hline Mg interchangeable & $\mathrm{cmol}_{+} \cdot \mathrm{kg}^{-1}$ & 0.71 & 2.08 & 0.30 & 0.88 & 0.55 & 1.81 & 0.83 \\
\hline $\mathrm{K}$ interchangeable & $\mathrm{cmol}_{+} \cdot \mathrm{kg}^{-1}$ & 0.45 & 0.82 & 0.51 & 0.74 & 0.39 & 0.72 & 0.41 \\
\hline Na interchangeable & $\mathrm{cmol}_{+} \cdot \mathrm{kg}^{-1}$ & 0.11 & 0.14 & 0.24 & 0.10 & 0.17 & 0.12 & 0.25 \\
\hline $\mathrm{Al}$ interchangeable & $\mathrm{cmol}_{+} \cdot \mathrm{kg}^{-1}$ & 0.05 & 0.70 & 0.31 & 0.21 & 0.34 & 0.37 & 0.44 \\
\hline $\mathrm{ECCE}^{1}$ & $\mathrm{cmol}_{+} \cdot \mathrm{kg}^{-1}$ & 5.61 & 11.99 & 3.14 & 8.09 & 3.87 & 11.78 & 5.11 \\
\hline Al saturation & $\%$ & 0.89 & 5.84 & 9.87 & 2.60 & 8.79 & 3.14 & 8.61 \\
\hline B & $\mathrm{mg} \mathrm{kg}^{-1}$ & 0.32 & 0.32 & 0.32 & 0.32 & 0.48 & 0.36 & 0.48 \\
\hline $\mathrm{Fe}$ & $\mathrm{mg} \mathrm{kg}^{-1}$ & 34.20 & 41.56 & 21.64 & 30.00 & 38.04 & 34.20 & 51.68 \\
\hline $\mathrm{Mn}$ & $\mathrm{mg} \mathrm{kg}^{-1}$ & 10.24 & 10.32 & 1.72 & 21.12 & 8.28 & 29.28 & 58.24 \\
\hline $\mathrm{Cu}$ & $\mathrm{mg} \mathrm{kg}^{-1}$ & 2.00 & 1.68 & 0.52 & 0.68 & 3.08 & 1.04 & 1.52 \\
\hline $\mathrm{Zn}$ & $\mathrm{mg} \mathrm{kg}^{-1}$ & 0.56 & 0.80 & 0.08 & 0.08 & 3.32 & 0.44 & 0.64 \\
\hline
\end{tabular}

${ }^{1}$ Effective cationic capacity exchange.

The predominant soils in southern Chile are volcanic ash derivatives, such as the trumao soils or Andisols, which include modern and recent ash deposits; "rojos arcillosos" or Ultisols, corresponding to ancient deposits; and "transicionales" or Transitional, with intermediate characteristics between the Andisols and Ultisols. The physical parameter of apparent density was analyzed in these soils (Table 5), and the measured values were as expected for these three kinds of soils. The lowest values are characteristic of the Andisols soils, which typically have high water retention capacity. The highest values correspond to Ultisols soils, which typically have very dense and heavy textures. Intermediate values were observed for the Transitional soils.
Soils identified as suppressive or conducive did not segregate by soil category (i.e., Andisol, Ultisol or Transitional) and therefore had variable apparent density values. This physical parameter does not appear to have any relationship with either the suppressive or conducive properties of the tested soils.

\section{Discussion}

Soils suppressive to the take-all disease of wheat have been reported worldwide (Cook and Baker, 1983; Hornby, 1998; Garveba et al., 2004). In Chile, however, there have been no reports regarding the presence of suppressive soils, despite the fact that take-all is one of the most damaging 
Table 5. Apparent density values of five suppressive and two conducive soils to the take-all disease of wheat.

\begin{tabular}{lccc}
\hline Soil & Suppressive or Conducive soil classification & $\begin{array}{c}\text { Soil } \\
\text { Classification }\end{array}$ & $\begin{array}{c}\text { Apparent Density } \\
(\mathrm{g} / \mathrm{cc})\end{array}$ \\
\hline 2 & Suppressive & Andisol & 0.81 \\
7 & Suppressive & Ultisol & 1.24 \\
9 & Suppressive & Andisol & 0.99 \\
10 & Suppressive & Transitional & 1.12 \\
16 & Suppressive & Andisol & 0.81 \\
6 & Conducive & Ultisol & 1.21 \\
17 & Conducive & Andisol & 0.84 \\
\hline
\end{tabular}

diseases affecting wheat grown in the Andisols soil in the southern part of the country (Andrade, 2004). In this research, at least 5 out of 20 tested soils were found to be highly suppressive to the take-all disease of wheat, as demonstrated by the transferability of this effect over the same but sterile soil background along with its expression in less than 40 days. Most of the soils with this characteristic were found on long-lasting and low-input wheat monoculture systems. In contrast, most of the soils collected from high-input and relatively short wheat monoculture systems ( 5 to 6 years), as with soil $\mathrm{N}^{\circ} 20$ and five other soils previously analyzed (data not shown), were found to be highly conducive. Some soils showing suppressiveness were also found in cases where wheat was alternated every 2 or 3 years with pasture. This result regarding soil suppressiveness and pasture has also been reported by Wildermuth (1980) investigating Australian soils.

The natural inhibition of the take-all disease of wheat, following the transference of a minute amount of a natural suppressive soil into the same but sterile soil background, has been widely reported (Weller et al., 2002; Hornby, 1998) and widely used to demonstrate the suppressive properties of that soil (Andrade et al., 1994; Weller et al., 2002; Borneman and Becker, 2007). The transferability of the suppressive effect has been attributed to the specific suppression provided, at least in part, by individual or selected groups of microorganisms (Weller, et al., 2002; Borneman and Becker, 2007). Rovira and Wildermuth (1981) showed that transferring $1 \%$ natural soil into fumigated or sterilized soil provides a background soil with unaltered physicochemical properties that correlates well with the suppression observed in the field. In our case, the reproducibility of this phenomenon was demonstrated with 2 soils previously classified as suppressive or conducive.

The physicochemical characteristics of the tested soils did not show any clear relationship with their suppressive or conducive properties. Within the suppressive and conducive soil groups, soils could have very different or quite similar physicochemical soil characteristics. The soil classification as Andisol, Ultisol, or Transitional within the groups was also variable and could not be used to predict suppressiveness nor conduciveness. While numerous reports suggest that plants have much more influence on microbial soil communities than the soil itself, there are other reports that describe the effects of the soil type on the variation of soil microorganisms. These results are, however, limited to specific species (Garveva et al., 2004). The relationship between some soil characteristics and suppressive soils has been reported for Fusarium solani var. coereleum suppressive soils (Tivoli et al., 1990), ginseng root rot (Chung et al., 1984), and tobacco black root rot (Défago et al., 1990). However, little is known about the influence of physico- 
chemical soil characteristics on the suppression of take-all disease of wheat. Chakraborty (1985) cited similar physicochemical characteristics in a study with suppressive and non-suppressive soils against Ggt. Additional studies have been conducted on physicochemical soil properties and their effect on specific biocontrol microorganisms to Ggt. Duffy et al. (1997) found a positive correlation between biocontrol of Ggt by Trichoderma koningii and iron, nitrate-nitrogen, boron, copper, soluble magnesium, and percent clay. Additionally, a negative correlation was observed between biocontrol of Ggt and soil $\mathrm{pH}$ and available phosphorous. Ownley et al. (1991) found a positive association of the biocontrol agent of Ggt, P. fluorescens strain 2-79, with soil $\mathrm{pH}$, percent sand, ammonium-nitrogen, sodium, sulfate-sulfur, and zinc concentration.

Our results with Chilean Ggt suppressive soils show that the chemical properties of conducive and suppressive soils overlap, except in the case of the micronutrient $\mathrm{Mn}$, for which the 2 conducive soils analyzed showed a higher Mn content compared to the suppressive soils. Various reports indicate that Ggt-conducive soil conditions in some wheat-producing areas of the U.S. are characterized by a low content of $\mathrm{Mn}^{+2}$ induced by a soil microflora that reduces $\mathrm{Mn}$ and inhibits plant defense mechanisms (Huber and McCay-Buis, 1993). Contrary to these findings, Andisol soils in southern Chile with high Mn content nevertheless exhibit high levels of take-all infection. Results obtained by Campillo and Andrade (2001) comparing sterilized suppressive and conducive soils demonstrated that variations in Mn content had no effect on disease expression in either suppressive or conducive soils. Furthermore, Mn content increased to very high levels in sterilized suppressive and conducive soils which did not affect the expression of the disease.
The microbiological characterization performed on a group of these suppressive and conducive soils will be reported in a future publication.

The tests carried out with 20 soils collected from the same number of low-input farms in southern Chile, mostly under wheat monoculture for a variable number of years, allowed us to identify soils with suppressive properties to the take-all disease of wheat. Under greenhouse conditions, this suppression against Ggt was expressed within 40 days.

The majority of soils possessing highly suppressive factors came from farms with a long history of wheat monoculture crop systems or those in which the land was converted to pasture every 2-3 years. In other cases, soils coming from highinput wheat crop systems, with a maximum of 5 to 6 years of monoculture, were found to be conducive to the disease.

Both suppressive and conducive soils encompass a wide spectrum of physicochemical characteristics and fail to reveal any clear tendency that could be associated with either property.

This is the first report of soils suppressive to the take-all disease in Chile.

\section{Acknowledgments}

This research was funded by FONDECYT Project No1960031. The authors wish to thank Dr. David Hornby, formerly Honorary Scientist at the Institute of Arable Crop Research (IACR, Rothamsted), Harpenden, Herts, UK, for his invaluable scientific support to this project. Also, thanks to Mr. Eduardo Contreras for his assistance in soil collection and processing and maintenance of greenhouse experiments. 


\title{
Resumen
}

\begin{abstract}
O. Andrade, R. Campillo, A. Peyrelongue y L. Barrientos. 2011. Suelos supresivos a Gaeumannomyces graminis var. tritici, identificados en monocultivos de trigo, en el sur de Chile. Cien. Inv. Agr. 38(3): 345-356. Incrementar el conocimiento del fenómeno biológico de los suelos supresivos es un aspecto crítico para el manejo y control biológico de patógenos vegetales asociados al suelo. Los Andisoles del sur de Chile son suelos altamente predisponentes para la pudrición radical del trigo, causada por el hongo Gaeumannomyces graminis var. tritici. Sin embargo, no existen antecedentes de investigaciones sobre la presencia de suelos supresivos a esta enfermedad en esta importante zona productora de trigo. La primera parte de este estudio tuvo como propósito identificar suelos supresivos a la pudrición radical del trigo para luego, caracterizar su microflora en la búsqueda de potenciales agentes de control biológico del agente causal. En base a la transferencia de la supresividad al mismo suelo evaluado, previamente esterilizado, veinte suelos colectados en diferentes áreas productoras de trigo del sur de Chile, fueron clasificados como supresivos o conductivos a la pudrición radical, bajo condiciones de inoculación artificial en invernadero. Se encontró propiedades altamente supresivas hacia la enfermedad en cinco de estos suelos, los cuales poseían un largo historial de monocultivo de trigo. Ambos tipos de suelos, supresivos y conductivos, comparten características físicoquímicas similares. Este es el primer reporte sobre suelos supresivos a la pudrición radical del trigo en Chile.
\end{abstract}

Palabras clave: Control biológico, Gaeumannomyces graminis var. tritici, suelos supresivos a la pudrición radical.

\section{References}

Andrade, O. 2004. Efectividad de diferentes desinfectantes de semilla sobre la pudrición radical (Gaeumannomyces graminis var. tritici) del trigo en el sur de Chile. Agric. Téc. (Chile) 64: 111126.

Andrade, O., D.E. Mathre, and D.C. Sands. 1994. Suppression of Gaeumannomyces graminis var. tritici in Montana soils and its transferability between soils. Soil Biol. Biochem. 26:397-402.

Borneman, J., and J.O. Becker. 2007. Identifying microorganisms involved in specific pathogen suppression in soil. Annu. Rev. Phytopathol. 45:153-172.

Campillo, R., O. Andrade, and E. Contreras. 2001. Variaciones en el contenido de $\mathrm{Mn}$ de dos suelos sometidos a esterilización y su efecto sobre la pudrición radical del trigo o "mal del pié". Agric. Téc. (Chile) 61:339-351.

Cook, R. J. and K.F. Baker. 1983. The nature and practice of the biological control of plant pathogens. American Phytopathological Society Press, St. Paul, MN, USA. 539 pp.
Chakraborty, S. 1985. Survival of wheat take-all fungus in suppressive and non suppressive soils. Pedobiologia 1(28):13-18.

Chung, Y.R., H.J. Kim, S.H. Ohh, and K.J. Park. 1984. Comparison of rhizosphere environments in soils suppressive and conducive to ginseng root rot. Korean Journal of Plant protection 23(3):142-146.

Défago, G., C.H. Berling, U. Burger, D. Haas, G. Kahr, C. Keel, C. Voisard, P. Wirthner, and B. Wütrich. 1990. Suppression of black root rot of tobacco and other root diseases by strains of Pseudomonas fluorescens: potential applications and mechanisms. Pages 93-108. In: D. Hornby, R. J. Cook, Y. Henis, W. H. Ko, A. D. Rovira, B. Schippers, and P. R. Scott (eds.). Biological control of soil-borne plant pathogens. CAB International, Wallingford, UK.

Duffy, B.K., B.H. Ownley, and D.M. Weller. 1997. Soil chemical and physical properties associated with suppression of take-all of wheat by Trichoderma koningii. Phytopathol. 87:1118-1124.

Garveba, P., J.A. van Veen, and J.D. van Elsas. 2004. Microbial diversity in soils: selection of micro- 
bial populations by plant and soil type and implication for disease suppressiveness. Annu. Rev. Phytopathol. 42:243-270.

Hornby, D. 1998. Take-all of cereals: a regional perspective. Wallingford, UK, CAB Int. 384 pp.

Huber, D.M., and T.S. McCay-Buis. 1993. A multiple component analysis of the take-all disease of cereals. Plant Dis. 77:437-447.

Mathre, D. 1992. Gaeumannomyces. Pages 60-63. In: L. L. Singleton, J. D. Mihail, and C. M. Rush (eds.). Methods for research on soilborne phytopathogenic fungi. The America Phytopathological Society, St. Paul, Minnesota, USA.

Ownley, B.H., D.M. Weller, and J.R. Aldredge. 1991. Relation of soil chemical and physical factors with suppression of take-all by Pseudomonas fluorescens 2-79. Pages 299-301. In: C. Keel, B. Koller and G. Défago (eds.). Plant growth promoting rhizobacteria: Progress and Prospects. IOBC/WPRS (Int. Org. Biol. Integrated Control Noxious Anim. Plants/ West Palaearctic Regional Sect.) Bull. 14.

Rovira, A.D., and G.B. Wildermuth. 1981. The nature and mechanisms of suppression. Pages 385-
415. In: M. J. C. Asher and P. J. Shipton (eds.). Biology and control of Take-all. Academic Press, New York.

Sparks, D.L. 1996. Methods of soil analysis. Part. 3. Chemical Methods. Soil Science Society of American Book Series Number 5. Soil Science Society of America, Inc., American Society of Agronomy, Inc., Madison, Wisconsin, USA. $1390 \mathrm{pp}$.

Tivoli, B., R. Corbiere, and E. Lemarchand. 1990. Relationship between $\mathrm{pH}$ of soils and their level of conduciveness to Fusarium solani var. coereleum and Fusarium roseum var. sambucinum responsible for the dry rot of potato tubers. Agronomie 10(2):63-68.

Weller, D.M., J.M. Raaijmakers, B.B. McSpadden, and L.S. Tomashow. 2002. Microbial populations responsible for specific soil suppressiveness to plant pathogens. Annu. Rev. Phytopathol. 40:309-348.

Wildermuth, G.B. 1980. Suppression of take-all by some Australian soils. Australian Journal of Agriculture Research 31:251-258. 